\title{
THE BILL OF EXCHANGE AS A MEANS OF PAYMENT AND SECURITY
}

\author{
Vojo Belovski, Associate Professor PhD, \\ Faculty of Law at the University "Goce Delchev"-Stip, Macedonia, \\ e-mail: vojo.belovski@ugd.edu.mk \\ Andon Majhosev, Associate Professor PhD, \\ Faculty of Law at the University "Goce Delchev"-Stip, Macedonia \\ e-mail: andon.majhosev@ugd.edu.mk \\ Ivana Dujovska, master student \\ on Faculty of Law at the University "Goce Delchev"-Stip, Macedonia, \\ e-mail: ivana_d1009@hotmail.com
}

Professional Paper

doi:10.5937/jouproman4-11436

\begin{abstract}
The bill of exchange is a kind of paper in order that its holder shall entitle the debtor named in the document to pay a certain amount of payments. The bill of exchange represents a means of payment and an instrument of providing the payment. It is an unconditional order given by the drawer to the drawee to pay a certain amount to the payee listed on the bill of exchange.
\end{abstract}

The bill of exchange is generally a paper on the orders but it can be issued as value paper to a name. It is such promissory notes where the issuer becomes a clause not by order. The bill of exchange though it appears as a means of payment and an instrument for securing the payment it also appears as a means of international payment, because the bill of exchange can become a modern instrument of crediting and payment. With the development of the credit market and the bill of exchange becomes a means for the drawer and the drawee. This means that instead of the bill of exchange to be paid after the expiry of a certain deadline for submission of the bill of exchange the holder may sell or discount, or to pay before the deadline for submission. With this the bill of exchange becomes a toll for discount.

Based on this we can conclude that the bill of exchange has the following roles:

-bill of exchange serves as a means of credit; payment;

-bill of exchange serves as means of

-bill of exchange serves as a means for discount by.

Keywords: security, bill of exchange of exchange, tender, an instrument for securing the payment.

\section{INTRODUCTION}

According to our law ${ }^{1}$, the bill of exchange serves as a means of payment and an instrument for securing the payment.

The bill of exchange represents a paper of value issued in the prescribed form in which its issuer (drawer) as unconditional order gives another person (drawee) at a specific time and place to pay a sum of money which is indicated on the bill of exchange, the user the same (payee) whose name is indicated on the bill of exchange.

Bill of exchange historically appeared at a certain stage of the socio-economic development of the then small countries in the Middle Age, due to the increasing development of international trade where goods purchased from abroad should be paid in the currency of the foreign country. That how appeared the need of payment not in cash but by giving etc. written document by which the indicated amount could be charged with the changer of the other country.

\footnotetext{
${ }^{1}$ Law of Exchange (" An official newspaper of Republic of Macedonia" no. 3/2002 and 67/2010)
} 
Bill of exchange gets its name because it served as a means of changing money in the supply of goods of more practical reasons, primarily because of the safe and secure handling of money. With the development of commodity economy, the bill of exchange appears as a medium of exchange, and later as a means of replacing the money. By using the bill of exchange could provide loans, then collecting funds, purchase of goods, payment services and other obligations.

With the development of the credit market, the bill of exchange becomes a tool for escompted by and reescompt. Instead the bill of exchange to be collected within a certain period of maturity, bill of exchange of exchange holder may sell or escompte, or to pay before the deadline of maturity but definitely reduce the amount of exchange. Once escompted the bill of exchange can be re-escomptedor in this case it becomes reescompt.

1. Sources of right to draft, development and unification of the bill of exchange of exchange right

Bill of exchange of exchange right was originally developed as customary law to XIX century when certain laws in certain countries have a major impact on bill of exchange of exchange right, and as the most important are: The French Commercial Code of 1807, the German general framework for the draft of 1848. And the English Bill of exchange of Exchange Act of 1882 . Therefore are created three bill of exchange systems.

1. French system (France, Netherlands, Greece, Argentina, Uruguay, Spain, Portugal, etc.).

2. German system (Germany, Austria, Denmark, Sweden, Norway, Italy, Belgium, Venezuela, Japan, Peru, etc.);

3. Anglo-Saxon system (UK, US, Canada, Australia, India).
Bill of exchange of exchange between these three legal systems there are big differences between and within individual systems, but also between the countries themselves.

To remove the difficulties surrounding the execution of trade operations by way of promissory note and avoid disputes arising from different national jurisdictions, at the end of XIX century appeared the desire for unification of the bill of exchange of exchange right.

For this purpose in 1852 was founded the Association for the unification of the bill of exchange of exchange right and the same year in Paris was presented the first draft of the bill of exchange of exchange law World. Later this issue dealt Association of International Law and the Institute of International Law.

But the first concrete steps in this regard have been achieved when the initiative of the Dutch government in 1910 in The Hague was made another draft of a single bill of exchange of exchange law. In 1913 in The Hague was adopted Hague uniformed version for the bill of exchange, but due to the commencement of World War I there was not significant acceptance of this Hague version.

In 1930 an international conference ${ }^{2}$ in Geneva adopted three international conventions in the field of bill of exchange of exchange right:

1. Convention on Uniform (uniform) bill of exchange of exchange law;

2. Convention on the regulation of certain conflicts of laws in the bill of exchange of exchange law;

3. Convention on the fees in the bill of exchange.

\footnotetext{
${ }^{2}$ Convention Providing a Uniform Law For Bills of Exchange and Promissory Notes (Geneva, 1930) The League of Nations
} 
All these three conventions signed and ratified by twenty European countries and several other countries outside Europe (Japinia, Brazil). The difference between countries which have accepted these conventions and "common law" consists in the fact that the European system is abstract paper bill of exchange, if allowed AngloAmerican law is a reference to the bill of exchange of major work.

Convention on the unvaried (lackluster) bill of exchange of exchange law was adopted on 7 June 1930 and consists of provisions concerning the content of the bill of exchange, the types of exchange, and of exchange activities and rules.

Most countries on the basis of these three conventions have adopted national (domestic) laws. National laws on bill of exchange complied with the provisions of the three conventions, so that in the country the provisions of the bill of exchange complied with the provisions of these conventions.

But this is not over the unification of exchange rights, contrary invested serious efforts in making unified system of exchange that would be widely accepted worldwide. Outstanding contribution to this system gives the United Nations Commission on Trade Law UNICITRAL which has produced the first draft project for an international draft.

When choosing the appropriate solutions taken into account for the purposes of international trade on previously gained experience about the difficulties and problems that arise in international payments in exchange for goods and services. After a long and successful work of UNICITRAL in 1988, it was adopted by the UN and adopted as a UN convention MA International traced own bill of exchanges and international bonds. This Convention shall be prepared based on the Geneva Conventions and
Anglo-Saxon bill of exchange of exchange law.

As national sources of bill of exchange of exchange right serving Bill of exchange of Exchange Act, the Securities and special provisions contained in the Contract Law.

The Law regulates the content, types of exchange, and of exchange activities and rules. Law bill of exchange has two parts: first, based on the Geneva Conventions and has international significance and the second, which regulate the bill of exchange for the needs of our country, as is the case with similar laws in other countries draft.

\section{Types of bill of exchange}

In the modern market may affect multiple types of bill of exchanges of exchange as follows:

1. Blanco bill of exchange of a future bill of exchange. It is characterized in that it lacks all the essential elements, such as labeling and variable amount predicted, but they can later be brought into it. Blanco bill of exchange of exchange is used as a means of ensuring the obligations of the borrower. Credit recipient issued a blank bill of such credit at the conclusion of the credit agreement. If a loan recipient $\mathrm{t}$ does not fulfill its obligation in the contract, such credit may fill a blank bill of that amount is not paid by the loan recipient.

2. The Department's draft bill of exchange arising from the sale of goods by way of credit. Buyer signing the bill of exchange to the seller ensures that loans taken will be returned. 
3. Business draft a bill of exchange of exchange issued by the user of the services of the contractors for the services provided on credit. Business bill of exchange could be escompt. Escompted by a decrease of the interest still unmatured claims when buying bill of exchange or payment of the amount of the bill of exchange which reads (nominal value) by reducing past due interest of expenses bank and bank commission. The bill of exchange transfer is performed by endorsement.

4. Credit bill of exchange exists when the person seeking credit gives own blank promissory note in advance and recognizes that the drawer is covered.

5. Domiciled bill of exchange of such a bill of exchange where the place of payment is not the same place of permanent residence of the drawee. In the draft indicated that the bill of exchange will pay a third party rather than the drawee, will pay off in another place, and not in the place indicated on the bill of exchange.

6. Circular draft bill of exchange is such that you can run and move further into or circulate. This is the case when a representative of a company should pay abroad.

But the most important division depending on the content of the bill of exchange distinguishes two types as follows:

\section{Drawn bill of exchange}

Drawn (drawn) is such draft bill of exchange in which her publisher (issuer) ordering another person (drawee) at the time predicted for the bill of exchange to pay to the person, the amount specified in the bill of exchange. The person who issues the bill of exchange (order, order) is called issuer, the person who should pay the bill of exchange is called the drawee, and the person in whose favor the bill of exchange is issued is called the payee. These are people who participate in the bill of exchange of exchange relations. The name drawn (drawn) promissory note received from the Latin word (trahere) which means pull.

\section{Own (solo) bill of exchange}

Own (solo) draft bill of exchange is one in which her publisher undertakes that at the time predicted the bill of exchange would pay a third party (payee) or by order of a third person, an amount indicated in the bill of exchange. Among stake and promissory note differences as followed:

- Unlike the drawn (drawn) draft where there are three people (drawer, drawee and payee), in his own (solo) bill of exchange there are only two parties: the issuer (the drawer of the bill of exchange) and the person that the bill of exchange should not pay - drawee they represent one person (the issuer of the bill of exchange) and the payee - in whose favor the bill of exchange is issued and which should be paid the amount specified in the bill of exchange.

- In the drawn (towed) draft clause for payment of the bill of exchange amount is "the way," in his own (solo) bill of exchange "will pay."

- In the drawn (drawn) draft is always a drawer tax paid to another person (drawee) while his own (solo) bill of exchange no promise of the issuer (drawer) of the bill of exchange that will pay the specified amount.

- Well, there are differences between certain drawn (drawn) and own (solo) on some draft questions of exchange activities. 
For promissory note sometimes used the term "promissory notes". However, this term is not found in the Bill of exchange of Exchange. By using this expression may lead to confusion in that it does not distinguish between their own (solo) draft and drawn (drawn) bill of exchange which contains clause that prohibited drawer issuance of duplicate bill of exchanges of exchange (the "promissory notes" ).

For a number of issues of promissory note provisions for the drawn (drawn) promissory note.

\section{Principles of the bill of exchange}

All authors consulted were unanimous that in the bill of exchange occur following principles:

- principle of Literacy (formality) of the bill of exchange;

- principle of incorporation;

- principle of exchange of a fixed duty;

- principle of exchange of rigor (abstraction);

- principle of solidarity draft;

- principle of autonomy draft (one-sided);

- principle of immediacy draft.

\section{Principle of literacy (formality) the bill of exchange}

According to this principle, bill of exchange of exchange debtors and all actions must be in writing in the manner, content and elements defined in the legislation. The only deviation from this principle apply to illiterate and blind, as in the case of a blank promissory note, which does not contain all the essential elements. There seems no doubt that this principle has undergone changes from the time the rule was applicable "unituactu"3, through the possibility of using a blank - a draft.

\footnotetext{
3 This has prevented the use of a blank bill of exchange of exchange.
}

The bill of exchange had to be made simultaneously by one person, one act, one ink, with a manuscript.

It can also be expected additional changes to this policy in the future. Changes arising as a result of the development of technology, the possibilities for using electronic signature and other techniques by which you will be taken debtors obligations.

In the current Law on Bill of exchanges of Exchange, marking that a bill of exchange of exchange must be printed on the bill of exchange of exchange syllable ${ }^{4}$, unlike the previous law, which was enough to write in the syllable of the document ${ }^{5}$, with a grammatical interpretation and literal application of the law prevents compiling the bill of exchange without using a printer.

\section{Principle of incorporation}

According to this principle, the bill of exchange obligation depends on the existence of the bill of exchange. At the same time there are two rights: the right of the bill of exchange which is obligatory Law and the bill of exchange, which is really right.

An exception to this principle is the procedure for depreciation of exchange, through which it is possible to exercise rights based on the decision of the court, which has replaced the bill of exchange ${ }^{6}$.

Just as the principle of writing, this principle will need to be resilient and adapt to the development of the art of the new ways of communication and new media of information.

\footnotetext{
${ }^{4} 3 \mathrm{M}$, Article 5, paragraph 1, item 1

5 Law for bill of exchange (office list FNRJ 104/1946, 16/1965, 54/1970, 1989), article 1, paragraph 1 item 1

${ }^{6}$ Bill of exchange, Articles 103-105.
} 


\section{Principle Fixed draft obligation}

The scope and content of the Bill of exchange liability arising from the content of the bill of exchange. It may be required and due only to what is provided in the bill of exchange of exchange in writing. In the historical development of this principle it becomes elastic when combining the principle of diligence.

\section{Principle of rigor draft (abstraction)}

The obligation of exchange of the creditor to take certain actions arising from the bill of exchange on time and within tight deadlines (presentations, protest, filing a lawsuit), the threat of loss of, or prejudice to the bill of exchange. In the past in accordance with this principle was provided and debt detention for people who do not fulfilled his draft obligation. Today, this rigor can be found through the abbreviated proceedings, in which is determined only formal truth.

Bill liability is inherently abstract or separated from the basic legal act, for which the bill is issued. In the past existed, causality between the basic legal act and the bill, but the causality abandoned thanks to the contribution of the German School and the interests of major creditors, with the bill becomes an abstract matter.

This principle is applied by the courts in deciding, which can be found confirmation in a number of court decisions and legal opinions at the head.

\section{Principle of solidarity draft}

According to this principle, if the principal debtor (acceptor) does not pay the bill of exchange, the other signatories of the bill of exchange jointly liable, in raising protest, of course if necessary protest.

The solidarity of the bill of exchange of exchange right differs from solidarity in contract law. Instead came to division of responsibility comes to transfer the obligation. If the bill of exchange amount is paid by the acceptor (the debtor), the liability ceases for all signatories of the bill of exchange, but if the bill of exchange obligation is fulfilled by another bill of exchange of exchange signed, then the obligation ceases for a bill of exchange of exchange signatories that follow in signatory exercised the obligation, but meeting all borrowers who signed the bill of exchange in front of the signatory who has fulfilled the obligation.

\section{sided) \\ Principle of autonomy draft (one-}

The obligation of each bill of exchange of exchange debtor is autonomous and has its own independent legal outcome, regardless of the validity of the signatures of previous signatories of the bill of exchange.

This principle is contained in our draft law. An exception to this principle is the responsibility of intervening by accepting (acceptor for honor - honorant), which corresponds to the same way that suits the taxpayer for that intervention.

\section{Principle of immediacy draft}

According to the principle of immediacy, there is fiction in a direct legal relationship between each bill of exchange of exchange debtor and creditor of exchange. The creditor may apply to each debtor to pay the amount the bill of exchange $^{7}$, of course, since previously turned to the main bill of exchange of exchange debtor's address failed, the bill of exchange amount is not paid and raised protest, if necessary raising protest.

\footnotetext{
${ }^{7}$ Bill of exchange, Article 57
} 


\section{Debtors works}

With the legal regulations specify certain debtors actions must be carried out each debtor or creditor.

\section{Issuance of promissory note}

Issuing such a draft Bill of exchange to exchange activity a unilateral declaration ordering the drawer to the drawee to pay a certain amount to the payee. In this way it comes to establishing a bill of exchange of exchange and legal relationship between the drawer, the drawee and payee.

In connection with the issuance of the bill of exchange there are certain rules: Drawn bill of exchange may be registered by order of the issuer; Drawn bill of exchanges of exchange may be drawn for account of a third party; Drawn bill of exchange may be drawn to the drawer; Drawn bill of exchanges of exchange may be payable at the third person in the place where the drawer or elsewhere - domicileddrawn bill of exchange of exchange; The promissory note may be payable in the third person or place outside the residence of the drawee. $^{8}$

If the amount of the bill of exchange is referred to with words and the amount specified in figures not match valid amount specified in words. If the amount of the bill of exchange is written several times in letters or more times in numbers, valid is the lowest amount. ${ }^{9}$

He that the bill of exchange will be signed as agent for another, though it was not authorized, shall be personally liable for it, and if it has paid shall have the same rights as the person for whom signed as representative. ${ }^{10}$ The drawer fits that bill of exchange will be accepted and paid. The drawer can get rid of the responsibility for

\footnotetext{
${ }^{8}$ www.nbrm.gov.mk

${ }^{9}$ www.nbrm.gov.mk

${ }^{10}$ www.nbrm.gov.mk
}

the acceptance, but can't get rid of the responsibility for it.

\section{Transferring promissory note (endorsement)}

One of the most important features of the bill of exchange is its endorsement. Endorser word meaning "back" because the bill of exchange transfer from one person to another is recorded on the back of the bill of exchange ${ }^{11}$. Only in exceptional cases endorsement can be written on the face of the bill of exchange, the continuation of the bill of exchange or document of "Alon" (paper sticks to the bill of exchange for an additional statements). With the endorsement transfers all the rights arising from the bill of exchange.

The endorsement may only include the endorser's signature - a blank endorsement. Blanco-endorsement to be valid, must be written on the back of the bill of exchange or alone. When the endorsement of blank bill of exchange of exchange holder may: ${ }^{12}$

- to fill in the blank endorsement with his own name or the name of another person;

- further endorse blank bill of exchange of exchange or on behalf of another person; and

- simply hand the bill of exchange to a third person without filling out the blank endorsement and without new endorsement.

Endorser fits that bill of exchange will be accepted and paid, unless the endorsement otherwise specified.

\footnotetext{
11 Dimitrovska - Antovska, Snezana, Bill of exchange - concept and types, debtors work and draft rights Notary No.5. Skopje

12 www.nbrm.gov.mk
} 
Endorser may prohibit the bill of exchange further endorsement in that case does not fit persons to whom the bill of exchange will be later endorsement. The person holding the bill of exchangebe considered its legitimate holder, if they prove their right to an uninterrupted series of endorsements. This applies in cases when the last endorsement is blank. After a blank endorsement follows another endorsement, it is considered that the signatory of the other idosament acquired the bill with blank endorsement. Erased endorsements in terms of their proof, be deemed to exist. If anyone on any basis that currently remain without bond, whoever has the bill and who proved their right as permitted by law is obliged to deliver the bill. Notwithstanding the bill is passed, provided that the holder acquired the bill by gross negligence or by committing a crime intentionally.

\section{The acceptance of promissory note}

The holder of drawn bill of exchange, and the person who holds the bill of exchange may be arriving, it be submitted for acceptance in the place of his residence. The drawer may prohibit the bill of exchange to be submitted for acceptance, except in cases when: ${ }^{13}$

- The drawn bill of exchange is payable at the third person;

- The promissory note is payable in a place outside the place of living or staying drawee; and

- The drawn bill of exchange is a certain time on demand.

Acceptance shall be written of the draft and is expressed with the words "admit", "received", "accepted" or any other word with the same meaning, as acceptance is considered the signature of the drawee when affixed on the face of the bill of exchange.
When the drawn bill is payable at a certain time on demand or based on a decision to be submitted for acceptance within a certain limit, the acceptance shall be dated when given, unless the holder of the bill seeks to dated on the day when the bill of exchange submitted for acceptance. It is thought that the drawee refused acceptance of the bill if written acceptance deleted before they return the bill of exchange. Until proven otherwise, it is considered that acceptance is deleted before returning the bill of exchange.

\section{Aval (draft warranty)}

Payment of the drawn his own draft bill of exchange for the entire amount or a part thereof may be provided by aval. Aval can be provided by any third party, and one of the signatories of the bill of exchange. ${ }^{14}$ It is expressed with the words "per aval", "as guarantor", "how emec" or any other expression with the same meaning. From Avalon need to see whom it is provided. If it can't be seen, it is considered to be of a drawer. The aval maker match as corresponding person guaranteed. By paying the bill of exchange, the aval maker acquires rights arising from the bill of exchange of exchange against the person guaranteed, as well as against the persons responsible in the bill of exchange.

\section{Intervention in draft}

The drawer, endorser or bill of exchange of exchange the aval maker may appoint a person who will inform him of whom intervened. If intervening overdue it be liable for damages that may arise due to it exceeding height as necessary, to accept or pay - intervening. Intervening may, under the conditions prescribed by this law to accept or pay for any debtor against whom it may be a request for recourse.

\footnotetext{
${ }^{13}$ www.nbrm.gov.mk
} 


\section{Reproduction of draft}

Drawn bill of exchange may be issued in two or more identical copies. The bill of exchange of exchange syllable of each sample must be made the same serial number, otherwise each sample is valid as a separate bill of exchange. Every holder of a bill of exchange which does not state that it is issued only in one sample may be required to provide further samples at his own expense.

\section{Transcripts and altering the bill of exchange}

Every holder of a bill of exchange of exchange has the right to make a copy thereof. The transcript must be identical to the contents of the original bill of exchange with the endorsements and all other provisions therein. The copy must specify where the copy ends. If made syllable of the bill of exchange, those who have signed the bill of exchange after the altering liable by the altered type, and the previous signatories shall be liable under the original syllable.

\section{Paying the bill of exchange}

The drawn and own bill of exchange payable on a certain day, at a specific time on demand or on a particular day from the date of issue shall be submitted for payment on the day of payment or one of the two working days that immediately after the date of payment. By paying the bill of exchange comes to the termination of the legal relationship with bill of exchanges of exchange. $^{15}$

When paying the bill of exchange, the drawee may require the holder of the bill of exchange to pass the bill of exchange, confirming the bill of exchange that it is paid off. The holder of the bill of exchange may not refuse partial payment. Case of partial payment the drawee may require

${ }^{15}$ www.nbrm.gov.mk payment to be recorded on the bill of exchange, and to be issued a receipt. ${ }^{16}$

Drawee may make payment on the bill of exchange before arrival. Passing the bill of exchange amount is borne by the holder of the bill of exchange. By passing the bill of exchange amount in whole person bound thereby shall be exempt from liability.

The holder of the stake or promissory bill of exchange may file a request for recourse against the endorser, the drawer and other payers as follows: ${ }^{17}$

1) upon arrival in case the bill of exchange is not paid in full or in part; and

2) prior to arrival when:

- Acceptance is rejected, wholly or in part;

- Before or after the acceptance or liquidation of the assets of the drawee or stop payments even if the cessation was not confirmed by a court decision or the performance of its property was unsuccessful;

- When opened bankruptcy or liquidation of the property of the drawer of the bill of exchange which must be submitted for acceptance.

When the bill of exchange amount issued in currencies that have the same name but a different value in the country where the bill of exchange is issued in the country where the bill of exchange is payable, it is considered that the bill of exchange amount is expressed in the currency of the place of payment. On the legal effect of the bill of exchange will impact the death of the drawer or the loss of their legal capacity, if occurring after the issuance of the bill of exchange. ${ }^{18}$

\footnotetext{
${ }^{16}$ www.nbrm.gov.mk

${ }^{17}$ www.nbrm.gov.mk

${ }^{18}$ Manoleva - Mitrovska, prof. Dr. Dance, Securities - promissory note and check, p.142
} 


\section{People in bill}

Issuer's principal or issuer of the promissory note indicated on the face of the bill.

Drawee is the one who pays the bill in the drawer cover is located to him.

Payee is an individual or legal entity stated in the document to which the amount specified in the bill or beneficiary of the bill.

Holder of a bill is a person who holds the bill of exchange.

Issuers of the bill banks and payment agencies that issue certain types of bonds.

Endorser is the holder of the recovery that the endorsement.

Indosator the person to whom the bill is passed. It can be a drawer or drawee and any person any bill of exchange.

Avalist is a person with his signature on the bill or alone guarantee the payment of the amount specified in the bill.

Acceptor person receiving the bill obligation with a statement of its payment.

Intervens a person appointed by the drawer, endorser or avalistot in the bill in case of a need to accept or pay.

Copyist is a person who placed the authorization copy of bill while ensuring that the maker of the copy will hand the original bill of exchange or pay the bill amount

\section{Conclusion}

The bill of exchange is security means of payment in order based on law that apply the general rules for all securities on order. In fact the bill of exchange is far greater detail regulated form of security to us upon which highlights her character identification in relation to other securities. It is obligatory legal paper that always follows a certain amount. This indicates an extremely legal meaning of the bill of exchange, because the economy in the area of commodity-money situation is not as important.

But it still has a major role in the credit system, and during the development of trade and commerce she acquires its role as a substitute for money.

Thus the bill of exchange is primarily a lending facility for securing the claim. Also the bill of exchange is an important tool for ensuring not only in commodity money circulation, but also among some payment institutions, especially in the foreign trade exchanges.

With the development of the credit market and the bill of exchange becomes a means for escompt by and re-escompt. This means that instead of the bill of exchange to be paid after the expiry of a certain maturity of the bill of exchange holder may sell or escompt i.e. to pay before maturity. With this bill of exchange becomes a means for escompted by. Once escompted, the bill of exchange can be re-escompt with operation called re-escompt.

Based on this we can conclude that bill of exchange has the following roles;

1. The bill of exchange serves as a means of credit;

2. The bill of exchange serves as a means of payment;

3. The bill of exchange serves as a means for escompt by. 


\section{Used literature}

$>$ Bill of exchange of Exchange ( "Official Gazette" no. 3/2002 and 67/2010)

$>$ Dimitrov - Antovska, Snow White, Bill of exchange - concept and types, debtors work and draft rights Notary No.5. Skopje

Manoleva - Mitrovska, prof. Dr. Dance, Securities - promissory note and check, p.142.

Balajovikj Dr. Ljubomir, draft and checks law SFRY, Belgrade, 1947
Convention Providing a Uniform Law For Bill of exchanges of Exchange and Promissory Notes (Geneva, 1930) The League of Nations

Zakon o menici (sluzben list FNRJ 104/1946, 16/1965, 54/1970, 1989), article 1, paragraph 1 item 1

www.pravo.org.mk

www.finance.gov.mk

$>$ www.nbrm.gov.mk 